\title{
Nutritional values, chemical compositions and antimicrobial activities of fruit juice from pineapple (Ananas comosus L.) and coconut (Cocos nucifera L.) blends.
}

\author{
Olayinka T. Ogunmefun, Oluwakemi S. Asoso*, Babawale P. Olatunji and Omotola M. Ogundele \\ Department of Biological Sciences, Afe Babalola University, Ado-Ekiti, Nigeria
}

\begin{abstract}
This research was carried out to determine the nutritional values and antimicrobial activities of a mixed fruit juice from Coconut (Cocos nucifera) and Pineapple (Ananas comosus) which was pasteurized at $80^{\circ} \mathrm{C}$ for 10 minutes. The Phytochemical components of the fruit juices were analysed whereby the amount of alkaloids was higher than the amount of flavonoids. The physical properties studied included $\mathrm{pH}$, titratable acidity and total solids. Nutritional, chemical compositions and antimicrobial activities of individual fruit juice and their blend were also carried out using standard methods. Sensory evaluation result showed a significant difference $(p<0.05)$ in their colour, flavour, taste and overall acceptability of the juice blend. Their $\mathrm{pH}$ and titratable acidity values that were in reversed manner confer on them longer storage period. The samples had good antimicrobial activities.
\end{abstract}

Keywords: Ananas comosus, Antimicrobial activities, Cocos nucifera, Chemical and nutritional compositions.

\section{Introduction}

Fruits are parts of flowering plants derived from the fertilization of specific tissues such as one or more ovaries [1]. They are highly perishable, non-staple foods which make-up about $39 \%$ of the food intake (fresh state or processed form) of people living in developing countries of Africa [2]. Based on fruits antioxidant capacities, they are used as indicators for healthy nourishment as well as protection factors of the human body against oxidative destruction [3]. Fruit juices are liquid, nonalcoholic products with certain degree of clarity and viscosity obtained through pressing or breaking up of fruits with or without sugar or Carbon dioxide addition [3]. The demands for nutritious foods such as fresh cut fruits and unpasteurized fruit juice by consumers have increased in the last decades owing to their low content of Sodium, cholesterol, fat, high concentration of Vitamin C, polyphenols and antioxidants that play important role in the prevention of cancer, heart diseases and diabetes [4]. Juice is classified as pure or pulp and are prepared to contribute vitamins to diet, serve as pleasant tasting beverage drink or as a form of preservation technique [5]. It contains small amount of protein, no fat, cholesterol and unless the pulp is included, contains no fibre [6,7]. Fruit juices are rich in minerals and vitamins $\mathrm{A}$ and $\mathrm{C}$, and could be fortified with more minerals and vitamins. The anti-oxidant components of fruit juice have beneficial long term health effects, such as decreasing the risk of cancer and heart disease [8].

The manufacture of juice from fruit and vegetable is as old as or older than Agriculture. During the ripening process, most fruits soften to the point where simply handling or transporting, yield more juice than flesh. Fruit juices are rich in vitamins and minerals and have regulatory functions to the body system such as augmentation of alkaline reserve of the blood and proper functioning of blood vessels including capillary, permeability and fragility as a result of contained falconoid. Juices increase body retention of Calcium, Magnesium and Nitrogen and are also good sources of quick energy. These qualities need to be maintained in technologies used to process fruit juices. Juice must have the characteristic colour, flavour and taste typical of the fruit from which it comes; it may be turbid or clear.

Coconut water is the liquid endosperm of Cocos nucifera. The coconut fruit is unique in that it accumulates large amounts of this liquid over periods of a year or more in its life cycle. The greatest amount of coconut water is found in young, green coconuts and provides nourishment for the growth of the solid endosperm (coconut meat) inside the hard shell of the fruit. When the fruit matures, both the solid endosperm and the remaining coconut water serve as nutrients for the developing embryo and seedling. Thus coconut water serves as a natural reservoir of nutrients to promote tissue growth [5].

Coconut (Cocos nucifera) is the stone of the drupes borne by the coconut palm, a member of the monocotyledonous family Palmae. It is known as the "wonder food" and is regarded as perfect diet because it contains almost all essential nutrients needed by the human body. It is nourishing, strengthening and fattening food. It has high oil content. The protein is of high quality and contains all amino acids essential for the growth and maintenance of the body. It is rich in $\mathrm{K}, \mathrm{Na}, \mathrm{Mg}$ and $\mathrm{S}$. The energy value of the dried coconut is 662 calories per $100 \mathrm{~g}$ [9].

Pineapple, (Ananas comosus), belongs to the order Bromeliales, family Bromeliaceae, and subfamily Bromelioideae [10]. It is the third most important tropical fruit in world production after banana and citrus. Around $70 \%$ of the pineapple produced in the world is consumed as fresh fruit in the country of origin. The processing of pineapple has made this fruit well known throughout the developed countries. Most of the pineapple 
Citation: Ogunmefun OT, Asoso OS, Olatunji BP, et al. Nutritional values, chemical compositions and antimicrobial activities of fruit juice from pineapple (Ananas comosus L.) and coconut (Cocos nucifera L.) blends. J Food Sci Nutr. 2018;1(2):40-6.

products of international trade are canned slices, chunks, crush (solid pack), juice, and especially fresh fruit.

From the realization of the demand of tropical fruits and fruit products in international markets, many countries began the processing of tropical fruits during the last two decades. Fruit juices, nectars and drinks are the most popular products made from tropical fruits. There is an increasing demand for fruit juices with the original characteristics of the fresh fruits and free from chemical additives. This results in the search of new technologies that are able to improve the sensorial, nutritional and microbiological quality of the fruit juices [11].

\section{Justification of the study}

Coconut and pineapple mixed fruit juice has nutritional values and a higher antioxidant property which make it medicinally important for the body in the prevention of diseases and infection and makes it better than chemically synthesized food supplements having side effect like high blood pressure and increase in heart rate. Antioxidant properties of each fruit juice confer on it the potential as a better antimicrobial agent than the conventional antibiotics which have different side effects, an example of an antibiotics is cephalosporin which its side effect are stomach discomfort, diarrhoea, blood abnormalities and rash or itching. The use of fruit juice as antimicrobial agents is encouraged especially in rural areas where there is no close access to health care facilities.

\section{Materials and Methods}

\section{Source of raw material}

Fully matured, fresh coconut and pineapple fruits were procured from Oja-Oba market at Ado-Ekiti, Ekiti state, Nigeria. They were transported to Afe Babalola University Microbiology laboratory, for subsequent studies. Chemicals and reagents used in this study were of analytical grades.

\section{Extraction of coconut water from coconut}

The coconuts were washed thoroughly with water to remove the sand and dirt on them after which they were washed with chlorine water to reduce the microbes that might be on the raw materials. The coconut water was extracted by cracking the coconut shell and the coconut water obtained was stored in a refrigerator at temperature of $4^{\circ} \mathrm{C}$ in a sterilized plastic container.

\section{Preparation of coconut milk extract}

The method described by Belewu, 2007 was used in the extraction of coconut milk [12]. Coconut milk was prepared by shelling the nut and the flesh was separated from the shell using a dull sterilized knife. The brown skin was removed from the coconut flesh with a clean razor blade and the flesh was thoroughly washed and later blended using a sterile blender. The blended flesh was put in a bowl and a little amount of warm water was added and left for a few minutes to extract the oil, milk and the aromatic compounds with cheese cloth. The extract was later filtered with $0.18 \mathrm{~mm}$ sieve and squeezed, so as to obtain a milky white opaque emulsion with a sweet coconut flavour while the chaff was discarded.

\section{Preparation of pineapple fruit juice}

The fruits were selected and were washed with $5 \%$ hypochlorite solution and rinsed thoroughly with distilled water. They were peeled with sterile stainless knife, cut into small pieces of about 3-4 mm thick. The diced pineapple was carefully loaded into an aseptically hygienic blender and blended. The juice was extracted by filtering the blended pineapple mass through a cheese cloth. The residue fibre in the cheese cloth was re-blended and strained for juice. The juice was bottled in an airtight screw cap sterilized glass bottles and refrigerated at $5^{\circ} \mathrm{C}$ prior to analysis and to prevent fermentation.

\section{Preparation of coconut/pineapple juice blends}

The coconut milk and water extracts were blended with pineapple juice in varying proportions such as 50:50 percent of pineapple extract and coconut extract, 100:0 percent of coconut extract without pineapple extract and 0:100 percent of pineapple extract without coconut extract. The blends were homogenised, bottled and pasteurised at $80^{\circ} \mathrm{C}$ for $10 \mathrm{~min}$ in a thermostatically controlled water bathe, cooled to room temperature $\left(27^{\circ} \mathrm{C}\right)$ and finally stored in a refrigerator at $5^{\circ} \mathrm{C}$ until analysed [13] (Table 1).

\section{Preservation of the formulated mixed fruit juice}

The formulated fruit juice was preserved by pasteurizing the drinks at a temperature of 80 degrees Celsius $\left(80^{\circ} \mathrm{C}\right)$ for 10 minutes. The pasteurized formulations were then filled in glass bottles which had tightly fitted lid and stored in a refrigerator at a temperature of $5^{\circ} \mathrm{C}$ [13].

\section{Shelf life determination of the formulated mixed fruit juice}

The shelf life of the final product was determined by checking the $\mathrm{pH}$ weekly, observation of gas production, change of colour and odours for a period of 1 month. The $\mathrm{pH}$ was used because when fermentation starts to take place there is the formation of alcohol which shifts the $\mathrm{pH}$ towards the basic region because of the ROH (alcohol) functional group [14].

\section{Microbial analysis of the formulated mixed fruit juice}

Microbial analysis was done on the fruit juice produced to check for bacteria and faecal coliforms and whether the pasteurization was adequate. Some of the samples were kept on the shelf (room temperature) and some in a fridge of an average temperature of $8^{\circ} \mathrm{C}$. The growths of microorganisms in the samples were determined for a period of 2 weeks.

\section{Isolation, characterization and identification of bacteria}

An aliquot of the pineapple, coconut extract and the mixture of the pineapple and coconut extract were serially diluted using the pour plate method of inoculation; $1 \mathrm{ml}$ of each diluted into $10^{-5}$ using sterile distilled water. $10^{4}$ dilutions were then pour plated on nutrient agar plate and $1 \mathrm{ml}$ of $10^{3}$ on potato dextrose agar plate for the respective isolation of bacteria and fungi from each of the fruit juice before and after pasteurization. The bacteria plates were incubated at $37^{\circ} \mathrm{C}$ for 24 hours and fungi cultivation plates at room temperature $\left(28 \pm 2^{\circ} \mathrm{C}\right)$ for 72 hours. $0.1 \mathrm{ml}$ of

Table 1: Formulation of coconut/pineapple juice blends.

\begin{tabular}{|c|c|c|}
\hline Samples & Coconut juice (\%) & Pineapple juice (\%) \\
\hline A & 50 & 50 \\
\hline B & 100 & 0 \\
\hline C & 0 & 100 \\
\hline
\end{tabular}


each juice sample was obtained aseptically, diluted and plated. At days 0, 5 and 10, serial dilution was carried out on each bottle of the pineapple, coconut extracts and the mixture of pineapple and coconut extract respectively and $0.1 \mathrm{ml}$ of $10^{3}$ for fungal growth and $10^{4}$ for bacterial growth were plated and incubated at $37^{\circ} \mathrm{C}$ for 24 hours for bacteria and for fungi at room temperature for 72 hours. The colonies obtained for bacteria was counted using colony counter and each distinct colonies from each plates were purified by sub culturing on nutrient agar plate to get a pure culture and then the pure cultures were then transferred to nutrient agar slant and stored at $4{ }^{\circ} \mathrm{C}$ for later use. The isolates were identified using morphological and biochemical tests according to Bergeys manual of systematic bacteriology [15].

\section{Identification of fungi}

Two drops of lactophenol blue with cotton wool was dispensed on a clean grease free slide. Using a sterile inoculating loop, a mycelia mat was transferred on the fluid and pressed so that it mixes well with the strain. The mycelia mat was then covered with a clean cover slip. The slide was observed under low power objective of microscope.

\section{Sensory analysis of the formulated mixed fruit juice}

The sensory analysis was carried out using 10 member panelists; which was done after pasteurization; it consisted of five males and five females whose ages ranged from 20 to 30 years of regular juice drinker, who were trained for one week with pasteurized pineapple juice, pasteurized coconut extract, and the final mixed fruit juice samples that were formulated. The panelists consist of students of Afe Babalola University, Ado-Ekiti, Ekiti State, Nigeria. The sensory qualities evaluated were: Colour, Flavour, Taste and Overall acceptability. The coconut/pineapple juice blends were served with clean glasses to individual panelist. The order of presentation of samples to the panel was randomized and they were instructed to express their feelings about the samples by scoring the sensory attributes like flavour, aroma, taste, mouthful and overall acceptability, portable water was provided to rinse the mouth between evaluations. Each sensory attribute was on a 5-point Hedonic Scale with (5: like very much, 4: like moderately, 3: neither like nor dislike, 2: dislike moderately and 1: dislike very much [16].

\section{Antimicrobial Activities}

\section{Test microorganisms}

Eight microorganisms were used in this study, consisting of four bacterial strains and four fungal strains. One was gram positive (Staphylococcus aureus) while three were gram negative (Escherichia coli, Shigella dysentriae, Samonella typhi). The four fungal stains used were (Candida albicans, Aspergillus niger, Aspergillus flavus and Penicillum notatum). All microorganisms were obtained from the Department of Biological sciences, Afe Babalola University, Ado-Ekiti, Ekiti state, Nigeria.

\section{Antimicrobial tests}

Susceptibility of the test organism to the juice isolates were determined using agar well diffusion method with nutrient agar, pathogenic organisms; Escherichia coli and Salmonella species were swabbed separately in duplicates on four agar plates, after which the different zones of inhibition were measured and recorded [17]. For fungi, the test was done on potato dextrose agar plates and incubated at $28 \pm 2^{\circ} \mathrm{C}$ for 72 hours. Zones of inhibition were measured and recorded.

\section{Statistical Analysis}

Results were expressed as mean values and standard deviation of three (3) determinations. Data were analysed using a oneway analysis of variance (ANOVA) using Statistical Package for Social Sciences (SPSS) version 20.0 software 2011 to test the level of significance at $5 \%$ probability $(p<0.05)$. Duncan New Multiple Range Test was used to separate the means where significant differences existed according the method of Wahua [18].

\section{Results and Discussion}

Proximate composition is an important index to classify the nutritional value of a food material. The samples (fruit blend, coconut and pineapple fruit) indicate that they were all rich in vitamin $\mathrm{C}$, energy and also has high moisture content (Table 2).

These phytochemicals could result in the effective antibacterial potency observed with the plant extracts. The qualitative and quantitative phytochemical compositions of the samples which showed that they were having higher yield in phenols, reducing sugars, alkaloids, flavonoids and terprenols (Tables 3 and 4). This finding is in support with Brown et al., which described the antioxidant properties of medicinal fruit juices which are rich in phenolics compounds [19]. The medicinal properties of a sample are normally dependent on the presence of certain phytochemical principles such as alkaloids, terprenols, phenol and flavonoids which are the bioactive bases responsible for the pharmacological property.

Table 2. Proximate compositions of fruit blend, coconut and pineapple fruit juices.

\begin{tabular}{|c|c|c|c|c|c|c|c|c|}
\hline Samples & Moisture Content (\%) & Crude fat (\%) & Crude protein (\%) & Crude ash (\%) & Crude fibre (\%) & Carbohydrate (\%) & Energy (Kcal/100 g) & Vitamin C \\
\hline A & 92.32 & 1.70 & 0.87 & 0.12 & 0.00 & 4.99 & 38.74 & $45.535 \pm 1.24$ \\
\hline B & 92.58 & 4.00 & 1.79 & 0.26 & 0.00 & 1.37 & 48.64 & $44.623 \pm 1.30$ \\
\hline $\mathrm{C}$ & 89.55 & 0.00 & 0.52 & 0.19 & 0.00 & 9.74 & 41.04 & $38.900 \pm 0.17$ \\
\hline
\end{tabular}

A: Blend of Coconut and Pineapple fruit juices, B: Coconut Fruit Juice, C: Pineapple Fruit Juice.

Table 3. Qualitative phytochemical compositions of fruit blend, coconut and pineapple fruit juices.

\begin{tabular}{|c|c|c|c|c|c|c|c|c|c|c|}
\hline Sample & Phenol & Tannins & Steroids & $\begin{array}{c}\text { Cardiac } \\
\text { Glycosides }\end{array}$ & $\begin{array}{l}\text { Reducing } \\
\text { Sugars }\end{array}$ & Terprenols & Alkaloids & Flavonoids & Saponins & Glycosides \\
\hline$A$ & + & + & + & _ & +++ & ++ & ++ & + & _ & - \\
\hline$B$ & + & - & - & - & ++ & + & ++ & + & _ & - \\
\hline C & + & + & _ & _- & +++ & ++ & + & ++ & _ & + \\
\hline
\end{tabular}


Citation: Ogunmefun OT, Asoso OS, Olatunji BP, et al. Nutritional values, chemical compositions and antimicrobial activities of fruit juice from pineapple (Ananas comosus L.) and coconut (Cocos nucifera L.) blends. J Food Sci Nutr. 2018;1(2):40-6.

Table 4. Some quantitative phytochemical compositions of fruit blend, coconut and pineapple fruit juices.

\begin{tabular}{|c|c|c|c|}
\hline Samples & Flavonoids & Alkaloids & Tannins \\
\hline A & $23.917 \pm 0.892$ & $44.650 \pm 0.158$ & $0.088 \pm 0.007$ \\
\hline B & $28.437 \pm 0.135$ & $86.250 \pm 0.158$ & - \\
\hline C & $38.167 \pm 0.106$ & $0.923 \pm 0.048$ & $-000 \pm 0.000$ \\
\hline A $:$ Blend of Conins & $0.037 \pm 0.002$ \\
\hline
\end{tabular}

A: Blend of Coconut and Pineapple fruit juices, B: Coconut fruit juice, C: Pineapple fruit juice.

Table 5. Antioxidant properties of fruit blend, coconut and pineapple fruit juices.

\begin{tabular}{|c|c|c|}
\hline Samples & FRAP & Total phenols \\
\hline A & $33.883 \pm 0.892$ & $0.194 \pm 0.010$ \\
\hline B & $10.590 \pm 0.036$ & $0.080 \pm 0.010$ \\
\hline C & $11.676 \pm 0.420$ & $0.205 \pm 0.003$ \\
\hline
\end{tabular}

A: Blend of Coconut and Pineapple fruit juices; B: Coconut fruit juice, C: Pineapple fruit juice.

The antioxidant properties of the samples were carried out and it was observed that there was a higher value in Ferric reducing antioxidant power (Table 5). The sensory evaluation were examined using the following parameters; taste, flavor and colour.

The overall acceptance of the sample was also reported in Table 6 and it implies full acceptability of the juices for human consumption.

The physical properties such as the TSS (Total suspended solids) and TTA (Total Titratable acidity) of the samples were observed; whereby the TSS was higher than TTA. Microbial load of each sample juice before pasteurization and after pasteurization were shown in Table 7.

The mineral composition of the coconut and Pineapple fruit juices showed the presence of sodium, potassium, calcium, phosphorus and Iron. The sodium and potassium of the blend of coconut and pineapple fruit juices (A) was having the highest amount followed by the coconut fruit juice alone.

Before pasteurization, bacterial load of $32 \times 10^{4} \mathrm{cfu} / \mathrm{ml}$ was recorded from the blend of both fruits (sample A), $20 \times 10^{4} \mathrm{cfu} /$ $\mathrm{ml}$ for coconut (sample B) and $16 \times 10^{4}$ for pineapple (sample C) while fungi load of $7 \times 10^{3} \mathrm{cfu} / \mathrm{ml}$ was recorded for sample A, $3 \times 10^{3} \mathrm{cfu} / \mathrm{ml}$ was recorded for sample B and $5 \times 10^{3}$ for sample C. No bacteria and fungi growth was recorded after pasteurization reason being that the pasteurization sterilized each samples. From the unpasteurized fruit juice, few organisms were isolated, (4 bacteria and 4 fungi). The bacterial species isolated were; Zygomonas mobilis, Micrococcus luteus, Aeromonas hydrophilus and Lactobacillus coryneformis and fungi isolated were Aspergillus niger, Penicillum itallicum, Candida krusei and Schizosacchromyce spombe. The characterization and identification of the isolated organisms were represented in Tables 8-11.

Antibacterial and antifungal studies were carried out on each sample; the bacteria species used were Salmonella typhi, Staphylococcus aureus, Shigella dysenteriae and Escherichia coli. While the fungi used were Candida albicans, Aspergillus niger, Aspergillus flavus andPenicillumnotatum. Staphylococcus aureus being the most susceptible with zones of inhibition of $9.0 \mathrm{~mm}$ for the fruit blends, $24.0 \mathrm{~mm}$ for coconut juice, and $16.0 \mathrm{~mm}$ for pineapple, followed by Shigella dysenteriae with inhibition zones of $10.0 \mathrm{~mm}$ for both fruit blends, $6.0 \mathrm{~mm}$ and
Table 6. Sensory evaluation of fruit blend, coconut and pineapple fruit juices.

\begin{tabular}{|c|c|c|c|c|}
\hline Samples & Taste & Flavour & Colour & $\begin{array}{c}\text { Overall } \\
\text { acceptance }\end{array}$ \\
\hline A & $4.10 \pm 0.57$ & $3.70 \pm 0.67$ & $3.60 \pm 0.70$ & $4.40 \pm 0.84$ \\
\hline B & $3.20 \pm 0.79$ & $3.40 \pm 0.52$ & $3.70 \pm 0.67$ & $3.90 \pm 0.32$ \\
\hline C & $3.50 \pm 0.71$ & $3.60 \pm 0.70$ & $3.70 \pm 0.48$ & $4.00 \pm 0.82$ \\
\hline
\end{tabular}

Table 7. Physical properties of fruit blend, coconut and pineapple fruit juices.

\begin{tabular}{|c|c|c|c|}
\hline Samples & A & B & C \\
\hline TTA & 2.96 & 4.44 & 5.23 \\
\hline TSS & 92.03 & 94.91 & 97.71 \\
\hline A: Blend of Coconut and Pineapple fruit juices, B: Coconut fruit juice; C: \\
Pineapple fruit juice; TTA: Total Titratable Acidity. \\
\hline
\end{tabular}

Table 8. Mineral composition of fruit blend, coconut and pineapple fruit juices.

\begin{tabular}{|c|c|c|c|c|c|}
\hline Samples & Sodium & Potassium & Calcium & Phosphorus & Iron \\
\hline A & 242.0 & 308.2 & 38.4 & 52.0 & 0.7 \\
\hline B & 12.5 & 29.7 & 14.3 & 36.4 & 0.5 \\
\hline C & 216.3 & 288.6 & 9.8 & 42.9 & 0.4 \\
\hline
\end{tabular}

A: Blend of Coconut and Pineapple fruit juices; B: Coconut fruit juice; C: Pineapple fruit juice.

Table 9. Microbial load (cfu/ml) of fruit blend, coconut and pineapple fruit juices.

\begin{tabular}{|c|c|c|c|c|c|c|}
\hline \multirow{2}{*}{ Sample } & \multicolumn{5}{|c|}{ DAYS } & \multicolumn{2}{c|}{10} \\
\cline { 2 - 7 } & \multicolumn{2}{|c}{$\mathbf{0}$} & \multicolumn{2}{c|}{5} & F \\
\cline { 2 - 7 } & Bacteria & Fungi & Bacteria & Fungi & Bacteria & Fungi \\
\hline A & $32 \times 10^{4}$ & $7 \times 10^{3}$ & - & - & - & - \\
\hline B & $20 \times 10^{4}$ & $3 \times 10^{3}$ & - & - & - & - \\
\hline C & $16 \times 10^{4}$ & $5 \times 10^{3}$ & - & - & - & - \\
\hline
\end{tabular}

A: Blend of Coconut and Pineapple fruit juice; $B$ : Coconut fruit juice; C: Pineapple fruit juice. Day 0 is before pasteurization while days 5 and 10 is after pasteurization.

$6.5 \mathrm{~mm}$ for coconut and pineapple fruit juices respectively and the least inhibition zone was in Salmonella typhi with the fruit blends having inhibition zone of $9.0 \mathrm{~mm}$, coconut having 8.5 $\mathrm{mm}$ and no inhibition zone in pineapple. No zone of inhibition was observed for all the three fruit juices on Escherichia coli. The fungi Aspergillus niger, Aspergillus flavus and Penicillum notatum were also resistant to all fruit juices because no zone of inhibition was observed in all.

The production flow chart of the fruit juice was shown in Figure 1 , which showed the process of how the fruit juice was produced.

Coconut and pineapple fruit juice blends had no zone of inhibition on Candida albicans while zones of inhibition for coconut and pineapple fruit juices were $4.0 \mathrm{~mm}$ and $8.5 \mathrm{~mm}$ respectively as shown in Figure 2 and Table 12.

The antibacterial properties for Salmonella typhi is in agreement with Bondose, which had an inhibition zone of $8.0 \mathrm{~mm}$ for the fruit blend. However, it did not agree with the results of all the fruit samples having $0.0 \mathrm{~mm}$. The result for Escherichia coli is not in agreement with Bondose, which had $4 \mathrm{~mm}$ zone while 
Table 10. Morphology and biochemical characteristics observed on pure isolates of fruit blend, coconut and pineapple fruit juices before pasteurization.

\begin{tabular}{|c|c|c|c|c|c|c|c|c|c|c|c|c|c|c|c|c|c|c|c|c|c|}
\hline \multirow{2}{*}{$\begin{array}{l}\text { Sam- } \\
\text { ple }\end{array}$} & \multirow{2}{*}{ Colour } & \multirow[t]{2}{*}{ Shape } & \multirow{2}{*}{$\begin{array}{l}\text { Eleva- } \\
\text { tion }\end{array}$} & \multirow[t]{2}{*}{ Edge } & \multirow[t]{2}{*}{ Surface } & \multirow{2}{*}{$\begin{array}{l}\text { Gram } \\
\text { stain }\end{array}$} & \multirow{2}{*}{$\begin{array}{l}\text { Cata- } \\
\text { lase }\end{array}$} & \multirow{2}{*}{$\begin{array}{l}\text { Starch } \\
\text { hydro- } \\
\text { lysis }\end{array}$} & \multirow{2}{*}{\begin{tabular}{|l|} 
In- \\
dole
\end{tabular}} & \multirow{2}{*}{$\begin{array}{l}\text { Oxi- } \\
\text { dase }\end{array}$} & \multirow{2}{*}{$\begin{array}{l}\text { Mo- } \\
\text { tility }\end{array}$} & \multirow{2}{*}{$\begin{array}{l}\text { Meth- } \\
\text { yl red }\end{array}$} & \multirow{2}{*}{\begin{tabular}{|l|} 
Citrateuti- \\
lization
\end{tabular}} & \multicolumn{7}{|c|}{ Triple sugar iron test (TSI) } & \multirow{2}{*}{$\begin{array}{l}\text { Names of identified } \\
\text { species }\end{array}$} \\
\hline & & & & & & & & & & & & & & $\begin{array}{l}\text { Glu- } \\
\text { cose }\end{array}$ & $\begin{array}{l}\text { Su- } \\
\text { crose }\end{array}$ & $\begin{array}{l}\text { Lac- } \\
\text { tose }\end{array}$ & \begin{tabular}{|l} 
Gas \\
produc- \\
tion
\end{tabular} & \begin{tabular}{|l|} 
H2S \\
produc- \\
tion
\end{tabular} & Butt & Slant & \\
\hline$A$ & Cream & Cocci & Convex & Entire & smooth & + & - & - & - & - & + & - & _ & + & - & + & + & - & $\mathrm{Y}$ & $\mathrm{Y}$ & Lactobacillus sp. \\
\hline$A$ & $\begin{array}{l}\text { Cream- } \\
\text { white }\end{array}$ & Cocci & $\begin{array}{l}\text { Convex } \\
\text { low }\end{array}$ & entire & smooth & + & - & - & - & - & - & - & - & + & - & - & - & - & $\mathrm{R}$ & $\mathrm{Y}$ & Candida krusei \\
\hline B & Cream & Rod & Convex & Entire & smooth & - & + & + & + & & & & - & + & + & + & + & - & $\mathrm{Y}$ & Y & Aeromonas spp. \\
\hline C & $\begin{array}{l}\text { Cream- } \\
\text { white }\end{array}$ & Cocci & Convex & Entire & smooth & + & - & - & - & - & - & - & - & + & - & - & - & - & $\mathrm{R}$ & $\mathrm{Y}$ & $\begin{array}{l}\text { Schizosaccharomy- } \\
\text { cespombe }\end{array}$ \\
\hline C & Brown & Rod & Flat & Entire & smooth & + & + & + & - & _ & + & _ & _ & + & _ & _ & _ & _ & $\mathrm{R}$ & $\mathrm{Y}$ & Zygomonasmobilis \\
\hline C & Yellow & Cocci & Convex & Entire & smooth & + & + & _ & - & + & - & _ & _ & - & _- & _ & - & - & $\mathrm{R}$ & $\mathrm{R}$ & Micrococcus leutus \\
\hline
\end{tabular}

Table 11. Fungal characteristics before pasteurization.

\begin{tabular}{|c|c|c|}
\hline Cultural Characteristics & Conidia arrangement under the microscope & Identity of isolate \\
\hline $\begin{array}{l}\text { Black conidiophores which made it } \\
\text { appear black in colour }\end{array}$ & $\begin{array}{l}\text { Hyphae septate and branched } \mathrm{n} \text { columella conidiophores long upright, aseptate, terminate in bulbous } \\
\text { vesicles. Conidia globose i-celled, black oval in shape and spiny slender hyphae branched and } \\
\text { aseptate. }\end{array}$ & Aspergillus niger \\
\hline Dirty green blue colonies & $\begin{array}{l}\text { The conidiophores were erect and branched around the apex, forming a brush like sterigmata. I-celled, } \\
\text { globose to petal in dry basipetal chain. }\end{array}$ & Penicillium italicium \\
\hline
\end{tabular}

WASHING

SORTING
S

PEELING \& CUTTING

凹

JUICE EXTRACTION

ॄ

FILTERING

凤

FILLING \& SEALING

そ

PASTEURIZATION

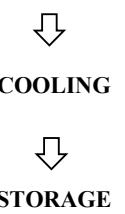

Figure 1. Production flow chart of juice.

all the tested fruit juice samples had no zone of inhibition at all. Shigella dysenteriae is in agreement with Bondose, which had $6.0 \mathrm{~mm}$ inhibition zone for samples used while the fruit blend, Coconut and Pineapple juices had 10.0, 6.0, and $6.5 \mathrm{~mm}$ zones respectively. All fruit samples tested had the highest zones of inhibition for Staphylococcus aureus as 9.0, 24.0 and $16.0 \mathrm{~mm}$ respectively and is in agreement with Abu (Figure 3) [20-24]. The antimicrobial activities of coconut is in agreement with Rukmini et al. [25].

The susceptibility of test organisms to commercial antibiotics (positive control) was expressed in Figure 4. Gentamycin among the conventional antibiotics inhibited all test organisms except Salmonella typhi. However, all the test organisms were resistant to Erythromycin, Tetracycline, Cotrimoxazole and Nalidixic

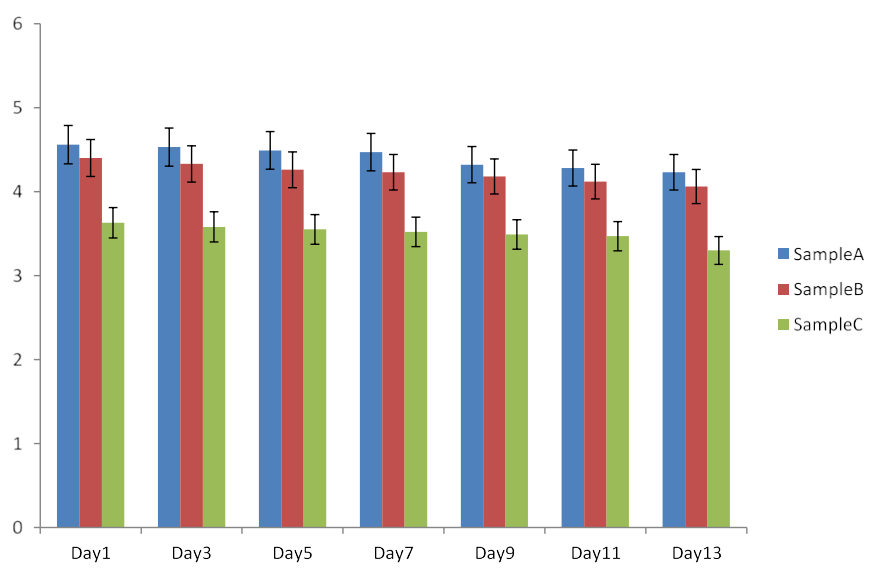

Figure 2. $p H$ of coconut and pineapple fruit juice with their blend at intervals. Sample A: Blend of fruit juice, Sample B: Coconut fruit juice, Sample C: Pineapple fruit juice.

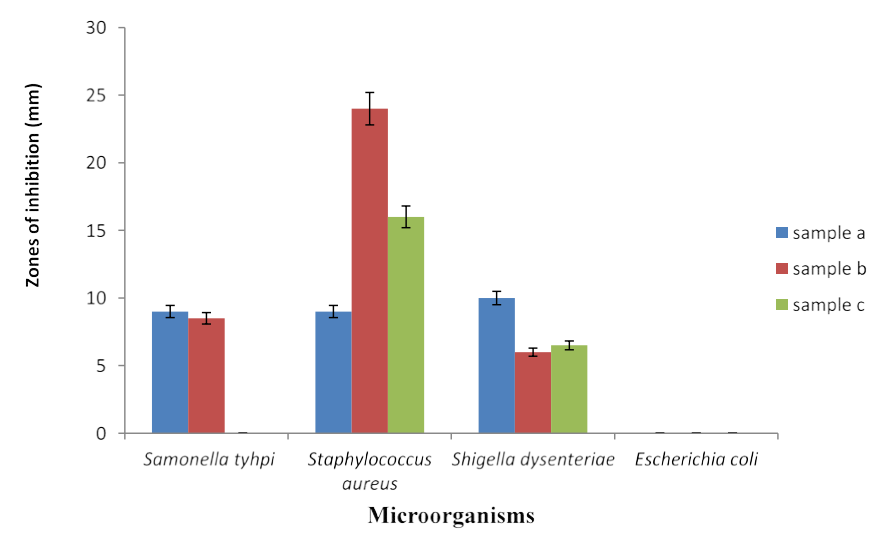

Figure 3. Antibacterial activity of coconut and pineapple fruit juice with their blend. Sample A: Blend of coconut and pineapple fruit juice; Sample B: Coconut fruit juice; Sample C: Pineapple fruit juice.

acid. Salmonella typhi was observed to be susceptible only to Nitrofuratoin with zone of $22.0 \mathrm{~mm}$. Staphylococcus aureus was inhibited with $13.0 \mathrm{~mm}$ and $10.0 \mathrm{~mm}$ by Gentamycin and Streptomycin respectively. Escherichia coli were inhibited by Ofloxacin and Gentamycin with zones of $25.0 \mathrm{~mm}$ and 19.0 $\mathrm{mm}$ respectively while Shigella dysenteriae was susceptible 
Citation: Ogunmefun OT, Asoso OS, Olatunji BP, et al. Nutritional values, chemical compositions and antimicrobial activities of fruit juice from pineapple (Ananas comosus L.) and coconut (Cocos nucifera L.) blends. J Food Sci Nutr. 2018;1(2):40-6.

Table 12. Antifungal activities of the samples.

\begin{tabular}{|c|c|c|c|}
\hline Samples & Candida albicans & Aspergillus flavus & Aspergillus niger \\
\hline A & - & - & - \\
\hline B & $4.0 \mathrm{~mm}$ & - & - \\
\hline C & $8.5 \mathrm{~mm}$ & - & - \\
\hline
\end{tabular}

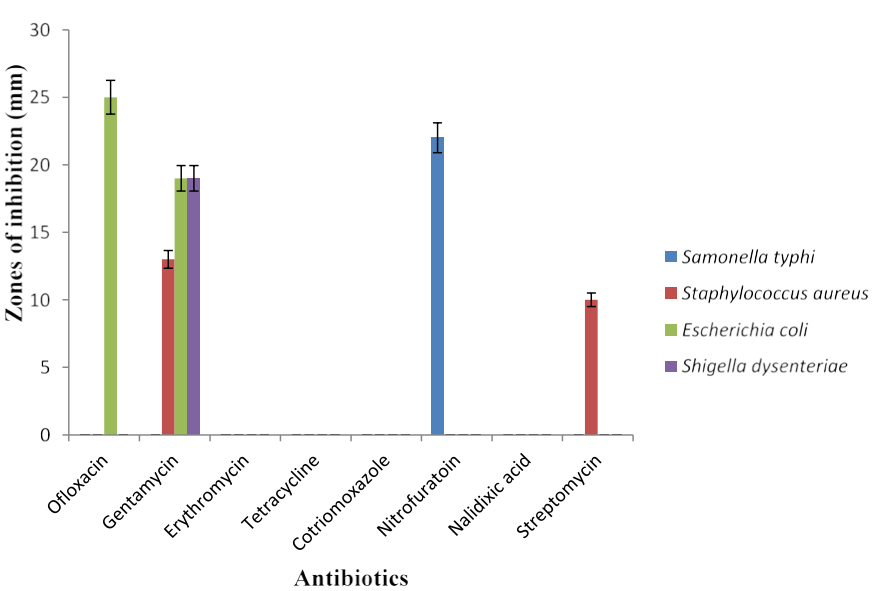

Figure 4. Antibiotics sensitivity test on bacteria species.

only to Gentamycin with zone of $19.0 \mathrm{~mm}$. Studies have been reported using antibiotics on test organisms with $C$. limonum juice extract which showed high susceptibility rate of several test organisms to Gentamycin [22]. However, in this study Escherichia coli, Shigella dysenteriae and Samonella typhi were susceptible to Ofloxacin, Gentamycin and Nitrofuratoin with zones of inhibition of $25.0 \mathrm{~mm}, 19.0 \mathrm{~mm}$ and $22.0 \mathrm{~mm}$ respectively [23-27].

\section{Conclusion}

Fruits both in fresh as well as in processed form not only improve the quality of our diet but also provide essential ingredients like vitamins, minerals, carbohydrates etc. It can be concluded that a fruit juice blend prepared from coconut and pineapple in a ratio of 50:50 percent can serve as homemade fruit juice which are better in terms of sensory parameters to the industrially packaged mixed fruit juices in the market, also having positive health benefits, also have great potential as antimicrobial agents against selected enteric pathogens and they can be used as an alternative medicine in the treatment or control of enteric bacterial infections.

\section{Acknowledgements}

The authors hereby acknowledge the founder and the governing board of Afe Babalola University, Ado-Ekiti, Nigeria for providing the enabling environment for conducting this research.

\section{References}

1. Mauseth PD, Sinisterra JV, Tsai SW, et al. Caricapapaya lipase (CPL): An emerging and versatile biocatalyst. Biotechnological Advantages. 2003;24(5):493-9.

2. Bates RP, Morris JR, Crandall PG. Principles Practices of Small and Medium Scale Fruit Juice Processing. Food \& Agriculture Org. 2001;146:1-226.

3. Costescu C, Parvu D, Rivis A. The determination of some physico-chemical characteristics for orange, grapefruit and tomato juices. Journal of Agro Alimentary Processes and Technologies, 2006;12(2):429-32.

4. Mattews KR. Microorganisms associated with fruits and vegetables. In: Matthews KR (ed.). Microbiology of Fresh Produce, Washington, DC: ASM Press. 2006;1:1-19.

5. Pursegloove JW. Tropical Crops, Monocotyledons. New York: Longman Singapore Publishers. 1992. 76-89:180224,440-79

6. Pao S, Fellers PL, Brown GE, et al. Formulation of Fresh Squeezed Unpasteurized Citrus Juice Blend. Fruit Processing Journal. 2001;7:268-71.

7. Parish ME, Microbial Concern in Citrus Juice Processing. Journal of Food Technology. 1991;45(4):128-32.

8. Boyer J, Liu R. Apple Phytochemicals and their health benefits. Journal of Food and Nutrition Research, 2004;3(5).

9. Bakhru HK. Foods that Heal. Orient Paper Backs, New Delhi. 2000;26-31.

10. Rohrbach KG, Leal FC, d'Eeckenbrugge G. History, distribution, and crop production. In: Bartholomew DP, Paul RE, Rohrbach KG (eds.) The Pineapple: Botany, production and uses. Wallingford, UK: CAB International. 2003;1-10.

11. Carneiro L, Iralla dos Santos Sa, Flávia dos Santos Gomes, et al. Cold Sterilization and Clarification of Pineapple Juice by Tangential Microfiltration. Desalination 2002;148:93-8.

12. Belewu MA, Belewu KY. Comparative Physico-Chemical Evaluation of Tigernut, Soyabean and Coconut Milk Sources. International Journal of agricultural Biology, 2007;9(5):785-7.

13. Emelike NJT, Ebere CO. Effect of packaging materials, storage time and temperature on the colour and sensory characteristics of cashew (Anacardiumoccidentale L.) apple juice. Journal of Food and Nutrition Research, 2015b;3(7):410-4.

14. Labuza PS, Labuza TP. Cotton candy shelf life. Journal of Food Processing and Preservation, 2004;28:274-87.

15. Holt JG, Krieg NR, Sneath PH, et al. (1994) Bergey's Manual of Determinative Bacteriology (9thedn), Baltimore, MD; Philadelphia; Hong Kong; London; Munich; Sydney; Tokyo: William and Wilkins.

16. Iwe MO. Enugu Nigeria Rejoint Communication Science Limited. Handbook of Sensory methods and analysis. 2010;75-8.

17. Mounyr B, Moulay S, Saad KI. Methods for in vitro 
evaluating antimicrobial activity: A review. Journal of Pharmaceutical Analysis.2016;6:71-9.

18. Wahua TAT. Applied Statistics for Scientific Studies. Aba, Nigeria: African Link Press. 1999; 26-49.

19. Brown JE, Rice-Evans CA. Luteolin rich artichoke extract protects low density lipoprotein from oxidation invitro free radicals Res. 1998;29:247-55

20. Abu-Shanab B, Adwan G, Abu-Safiya D, et al. Antibacterial activities of some plant extracts utilized in popular medicine in Palestine. Turkey Journal of Biology 2004;28;99-102.

21. Okeke MI, Iroegbu CU, Eze EN, et al. Evaluation of extracts of the root of Landolphiaowerrience for antibacterial activity. Journal of Ethnopharmacology. 2001;78(2-3):119-27.

22. Kumar S, Thippareddi H, Subbiah J, et al. Inactivation of Escherichia coli K-12 in apple juice using combination of high-pressure homogenization and chitosan. Journal of Food Science. 2009;74:M8-M14.
23. Mamta S, Jyoti S, Rajeev N, et al. Phytochemistry of medicinal plants. Journal of Pharmacognosy and Phytochemistry. 2013;1(6):168-82.

24. Omorayi BE, Bradley G, Afolayan A. Antioxidant and phytochemical properties of Carpobrotusedulis (L) bolus leaf used for the measurement of common infections in HIV/AIDS patients in Eastern Cape Province. BMC Complementary and Alternative Medicine. 2012;12:215.

25. Rukmini JN, Sunkari M, Chenna R, et al. Journal of International Society of Preventive and Community Dentistry 2017.

26. Salunkhe DK, Kadam SS. Handbook of Fruit Science and Technology, New York: MercelDekkar. 1995;614:614.

27. Kam, PCA, Liew S. Traditional Chinese Herbal medicine and anesthesia. Anesthesia 2002;57(11):1083-9.

\section{*Correspondence to:}

Oluwakemi Asoso S

Department of Biological Sciences

Afe Babalola University

Ado-Ekiti

Nigeria

Email: oyesolakemi@gmail.com 